\title{
Two Cases of Isolated Frontal Septal Cell Inflammation Treated with the Draf IIb Procedure
}

\author{
Yeon-Hee Joo, $\mathrm{MD}^{1,2}$ \\ ${ }^{1}$ Department of Otorhinolaryngology, Gyeongsang National University Changwon Hospital, Changwon and \\ Gyeongsang National University College of Medicine; and ${ }^{2}$ Institute of Health Sciences, Gyeongsang National \\ University, Jinju, Korea
}

\begin{abstract}
- ABSTRACT -
The frontal septal cell (FSC) is a medially based air cavity of the anterior ethmoid or the inferior frontal sinus, located in the interfrontal sinus septum. FSC pathologies are extremely rare although they are common frontal recess cells. We report on two patients with isolated FSC sinusitis presenting with frontal headache who were treated with Draf IIb endoscopic sinus surgery (ESS). Paranasal sinus computed tomography of the patients revealed a clear frontal sinus and FSC soft tissue density. The patients underwent a Draf IIb procedure through left-sided approach to treat FSC inflammation. After surgery, the patients no longer complained of headache, and the widened outflow tract was maintained without narrowing in endoscopic views during 2 years of followup. When a patient presents with continuous frontal headache, FSC inflammation should be considered. It can be successfully treated by Draf IIb ESS. (J Clinical Otolaryngol 2021;32:85-89)
\end{abstract}

KEY WORDS: Sinusitis · Frontal sinus · Sinus anatomy.

\section{Introduction}

The frontal septal cell (FSC) is a medially based air cavity of the anterior ethmoid or the inferior frontal sinus, located in the interfrontal sinus septum. ${ }^{1)} \mathrm{FSC}$, one of the group of cells communicating with the frontal recess including the agger nasi cells, supra agger frontal cells, supra bullar frontal cells and supraorbital cells, push the frontal sinus drainage pathway laterally and posteriorly. Because FSCs are located completely inside the frontal sinus, FSCs are not found during regular endoscopic sinus surgery (ESS). In addition, although FSCs are common frontal recess cells, FSC pathologies are extremely rare. Consequently, FSCs have not received much attention in the literature, with several FSC mucoceles reported, and one case of FSC inflam- mation treated with external osteoplasty. ${ }^{2-4)}$ We report on two patients with isolated FSC sinusitis presenting with frontal headache, who were successfully treated with Draf IIb ESS.

\section{Case Report}

\section{Case 1}

A 49-year-old male presented with frequent frontal headaches for 10 years. His symptoms usually recurred every 3 months and sometimes occurred several times per month. He had undergone paranasal sinus computed tomography (PNS CT) 10 years prior, when sinus surgery was considered to treat chronic sinusitis. However, he did not undergo sinus surgery at that time. His headache was aggravated several months previously, and he

논문접수일: 2021년 3월 23일 / 논문수정일: 2021년 4월 26일 / 심사완료일: 2021년 5월 18일

교신저자: 주연희, 51472 경상남도 창원시 성산구 삼정자로 11 , 창원경상국립대학교병원 이비인후과

전화: (055) 214-3863·전송: (055) 214-3262·E-mail: yhjoo@gnuh.co.kr 
had visited a rhinology clinic. There was no underlying disease and no symptoms other than headache. On endoscopic examination, the nasal septum was deviated to the left. PNS CT revealed a well-developed clear frontal sinus and FSC soft tissue density (Fig. 1). The FSC was divided into two independent spaces by a thin bony septum. We planned ESS through a left-sided approach even though the patient exhibited left septal deviation. This was because the FSC was angled slightly to the left, and a left-sided approach is easier for operating on a midline lesion for a right-handed surgeon. Under general anesthesia, wide frontal sinusotomy was performed to secure the working space. Next, a Draf IIb procedure was performed to approach the FSC, which involved removing the superior anterior attachment of the head of the middle turbinate to the septum and the floor of the frontal sinus, using cutting forceps and a curved drill. The thin bony wall identified along the medial side of the frontal sinus was punctured with a curved curette.

A thick mucopurulent discharge was sucked out, and the FSC was opened widely using a drill and debrider (Fig. 2A). The two divided spaces were connected by the removal of the thin bony septum (Fig. 2B). After the ESS, the patient no longer complained of headache and
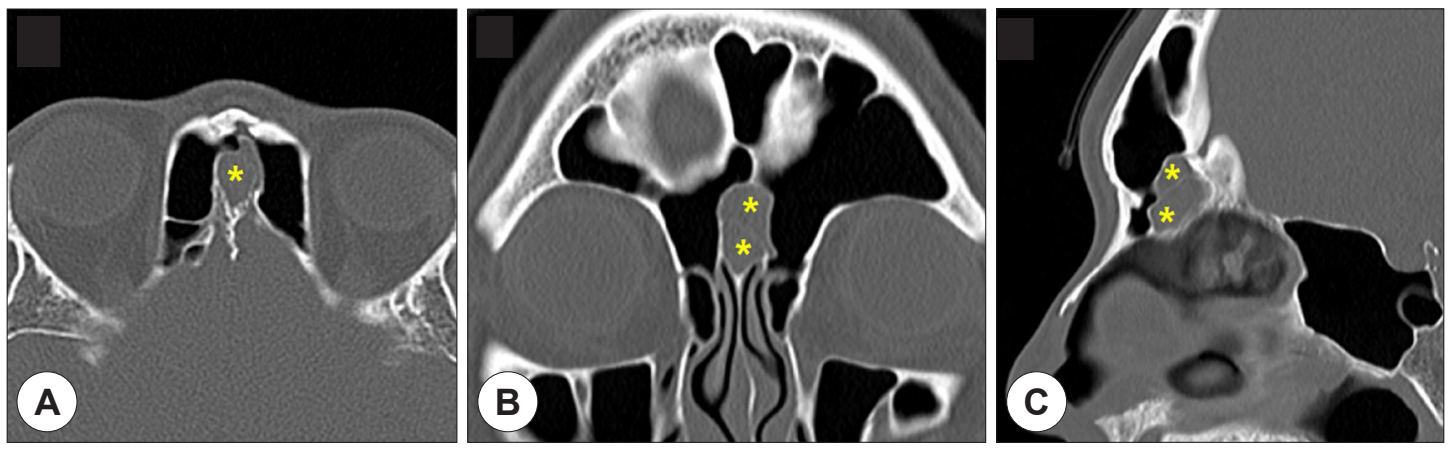

Fig. 1. Preoperative PNS CT images of Case 1. The PNS CT axial view (A) reveals FSC soft tissue density (yellow asterisk). The PNS CT coronal view (B) reveals a well-developed clear frontal sinus and an inflamed FSC divided into two independent spaces (yellow asterisk) by a thin bony septum. The sagittal view (C) showed inflamed FSC divided into two independent spaces (yellow asterisk) in front of crista galli.
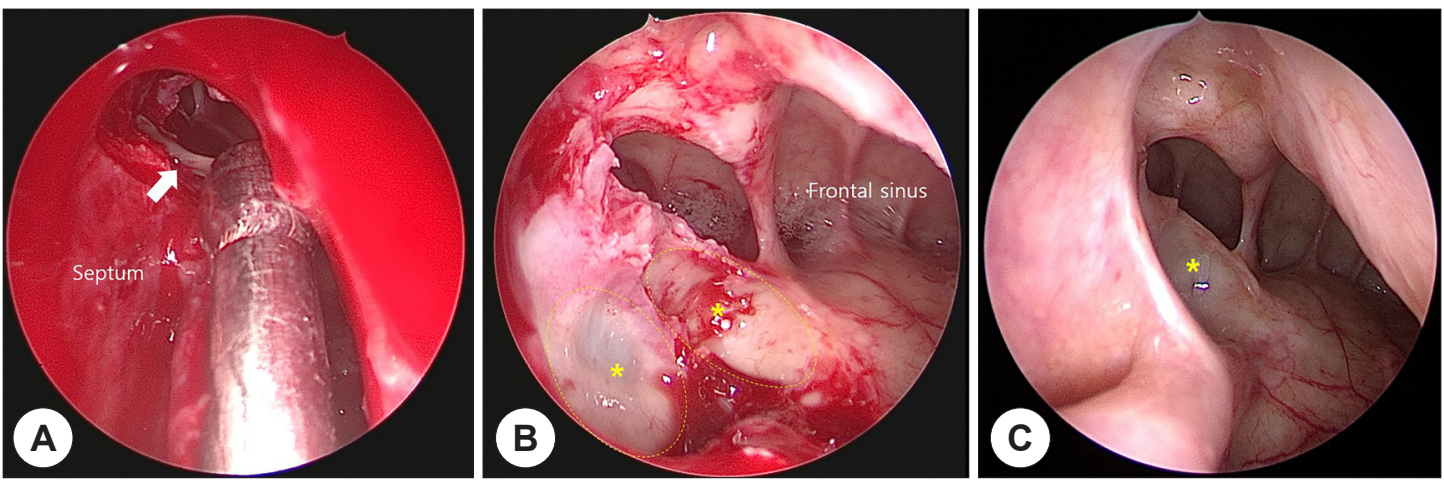

Fig. 2. Intraoperative and postoperative endoscopic findings of Case 1. Thick mucopurulent discharge (white arrow) was sucked out of the FSC during surgery (A). Two divided spaces (yellow dashed circle) were connected by the removal of a thin bony septum (yellow asterisk) (B). In postoperative endoscopies, the opened FSC (yellow asterisk) could be observed easily and the wide outflow tract was maintained without narrowing (C). 
the widened outflow tract was maintained without narrowing in endoscopic views during 2 years of follow-up (Fig. 2C).

\section{Case 2}

A 21-year-old male presented with a left frontal headache for 2 months. He had undergone ESS to treat chronic rhinosinusitis 6 months prior. Although the patient was treated with medical therapy including antibiotics and analgesics for 2 months, his headache continued. He had no other complaints. Endoscopic examination revealed patent frontal sinusotomy and antrostomy in the left nasal cavity. On PNS CT, the left frontal sinus was clear but exhibited FSC soft tissue density (Fig. 3). As in Case 1, we performed a Draf IIb procedure through a left-sided approach, under general anesthesia. Wide frontal sinusotomy had already been performed in the previous ESS. The superior anterior attachment of the middle turbinate was partially removed with cutting forceps, and the frontal sinus floor was removed toward the nasal septum medially using a curved drill. A thin bony wall observed along the medial side of the left frontal sinus was punctured, and mucopurulent discharge was identified inside. The FSC was opened widely using a drill (Fig. 4A and B). After ESS, the patient's headache improved, and the wide frontal recess was maintained without narrowing in endoscopic views during 2 years of follow-up (Fig. 4C).
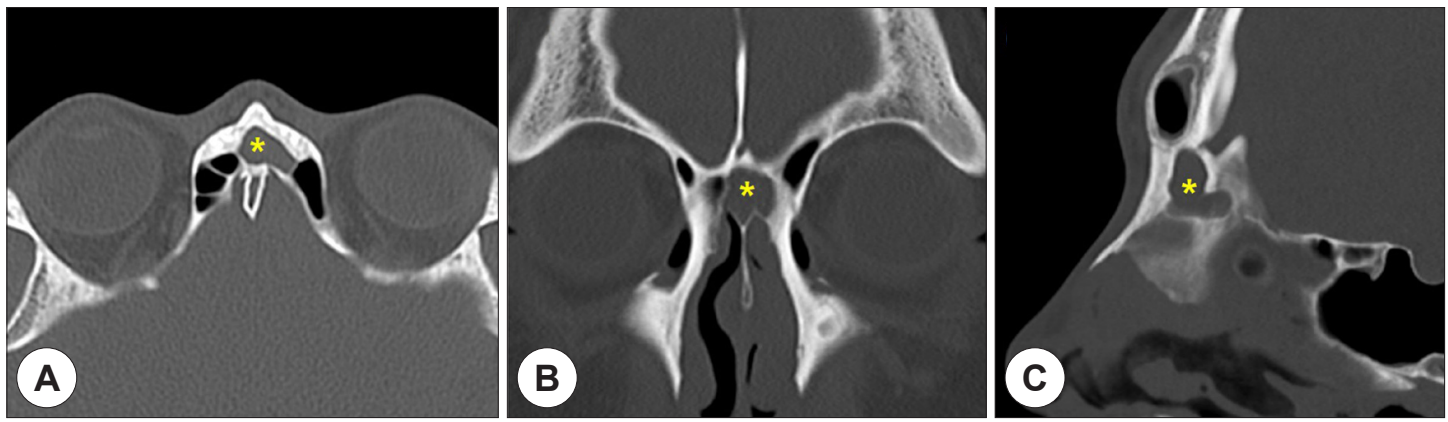

Fig. 3. Preoperative PNS CT images of Case 2. The PNS CT axial (A) and coronal (B) views reveal a clear frontal sinus and FSC soft tissue density (yellow asterisk). The sagittal view (C) showed inflamed FSC (yellow asterisk) in front of crista galli.
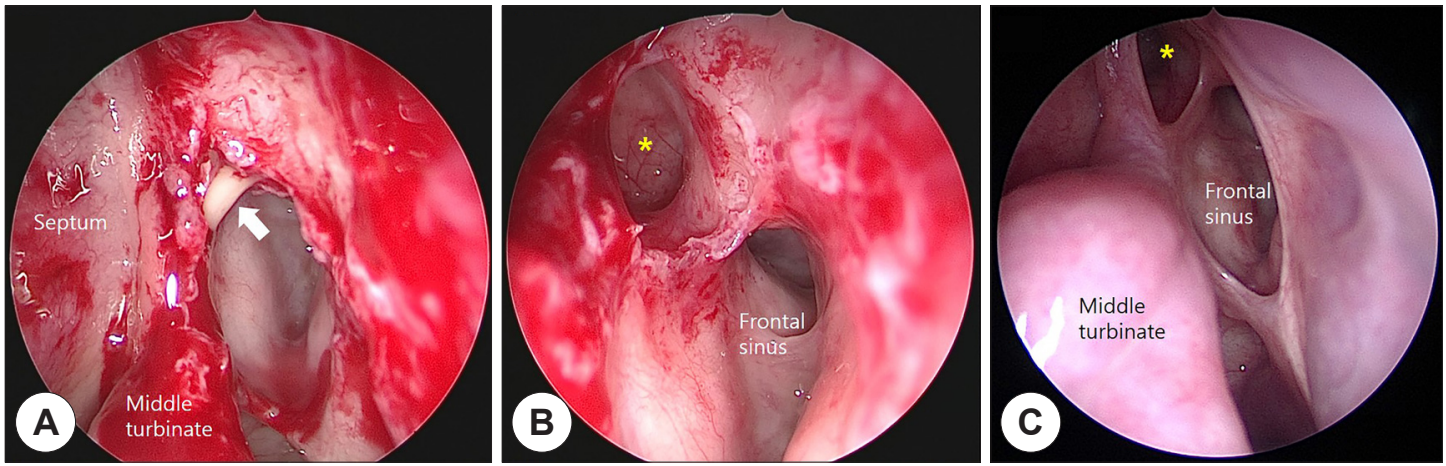

Fig. 4. Intraoperative and postoperative endoscopic findings of Case 2. Mucopurulent discharge (white arrow) spilled out of the FSC during surgery (A). The FSC (yellow asterisk) located medial to the frontal sinus ostium was widened after drilling (B). In postoperative endoscopies, the FSC (yellow asterisk) and frontal recess could be observed easily (C). 


\section{Discussion}

The FSC was defined as a cell confined to the thin septum separating the frontal sinuses in 1941. ${ }^{5)}$ The incidence of FSCs has been reported to vary between $11.6 \%$ and $34 \%{ }^{2)}$ In 2008, Som and Lawson found that FSCs were observed in 61 (30.5\%) of 200 cases. However, the study revealed that only 9 (4.5\%) of the 200 cases involved true FSCs, and the others were connected with the frontal sinus by diverticular extensions from the frontal sinuses. ${ }^{6}$ Thus, true FSCs without connections to the frontal sinus are rare.

Frontal recess cells such as agger nasi cells, supra agger frontal cells, and supra bullar frontal cells as well as FSCs are related to the development of frontal sinusitis. However, Kubota et al. reported that among various frontal recess cells, only supra bullar frontal cells were strongly associated with the development of frontal sinusitis, whereas FSCs were the least associated. ${ }^{7)} \mathrm{Be}-$ cause FSCs are completely medially located cells inside the frontal sinus, affect the outflow passage of the frontal sinus less than other frontal recess cells. Therefore, the presence of an FSC is not related to frontal sinusitis, and isolated FSC inflammation could occur regardless of frontal sinusitis, as in our two cases.

These two patients presented with headache only, without other nasal symptoms, and the locations of the headaches correlated well with the inflamed FSCs seen on PNS CT. Therefore, PNS CT is necessary in patients who only complain of frontal headache and do not exhibit any specific findings in the nasal cavity examination. With the development of CT, sagittal images as well as axial and coronal images can be examined, and accurate analysis of sinus anatomy is possible. However, an FSC is easy to miss, particularly if PNS CT reveals severe sinusitis in a large frontal sinus. Surgeons usually look for overall inflammation in each sinus while reviewing preoperative PNS CT scans. Frontal recess cells other than FSCs are removed during frontal sinusotomy even if those cells were not assessed in detail before surgery. However, an FSC cannot be approached during routine frontal sinusotomy such as a Draf I or Draf IIa procedure, because true FSCs are located completely inside the frontal sinus as mentioned previously, which is why an FSC cannot be found or identified during typical ESS. Thus, it is possible that an FSC was missed in the previous ESS in Case 2. To not miss an FSC during surgery, it is necessary to look for the presence of an FSC and associated inflammation at the PNS CT review and consider the appropriate approach before surgery.

Because surgeons operate surgical instruments inside the frontal sinus, it is better to approach from the side with a wide frontal recess. If the area of the frontal recess are similar on both side, a left-sided approach is easier for operating on a midline lesion for a right-handed surgeon. FSC was located superiorly and medially above the frontal ostium, there was a limit to the range of motion of curved instruments such as curved grasping/cutting forceps, giraffe forceps and frontal curette. Thus, Draf IIb sinus surgery is necessary to secure working space and remove an FSC wall, and a frontal sinus drill is needed to widen the ostium by drilling the frontal sinus floor. A navigation system would be helpful in patients with small FSCs and small frontal sinuses. Surgeons must make a frontal recess wide enough to check the operation site via endoscopic examination after surgery.

Although an FSC is likely to be overlooked in CT reviews and during ESS, attention is required because FSCs cause symptoms and can be successfully treated with surgery.

\section{Conclusions}

When a patient presents with continuous frontal headache, FSC inflammation should be considered even though the patient might have undergone ESS and 
exhibited a patent frontal sinus ostium in a previous endoscopic examination. PNS CT is necessary, and ESS using the Draf IIb procedure can successfully treat isolated FSC inflammation with headache symptoms.

\section{REFERENCES}

1) Wormald PJ, Hoseman W, Callejas C, Weber RK, Kennedy DW, Citardi MJ, et al. The International Frontal Sinus Anatomy Classification (IFAC) and Classification of the Extent of Endoscopic Frontal Sinus Surgery (EFSS). International Forum of Allergy \& Rhinology. 2016;6(7):677-96. http://www. ncbi.nlm.nih.gov/pubmed/26991922

2) Som PM, Lawson W. Interfrontal sinus septal cell: a cause of obstructing inflammation and mucoceles. AJNR American Journal of Neuroradiology. 2008;29(7):1369-71. http://www. ncbi.nlm.nih.gov/pubmed/18467519

3) Chua AJK, Chin DCW, Huang XY. Transnasal frontal intersinus septum takedown for frontal sinus pyocele. Eu- ropean Annals of Otorhinolaryngology, Head and Neck Diseases. 2019;136(4):321-3. http://www.ncbi.nlm.nih.gov/ pubmed/31023591

4) Milonski J, Pietkiewicz P, Urbaniak J, Kusmierczyk K, Olszewski J. Inflammation of the frontal intersinus septal air cell as a cause of headaches. International Journal of Surgery Case Reports. 2014;5(12):1292-4. http://www.ncbi.nlm.nih. gov/pubmed/25485764

5) Van Alyea OE. Frontal cells: an anatomic study of these cells with consideration of their clinical significance. Archives of Otolaryngology-Head \& Neck Surgery. 1941;34(1):11-23.

6) Som PM, Lawson W. The frontal intersinus septal air cell: a new hypothesis of its origin. AJNR American Journal of Neuroradiology. 2008;29(6):1215-7. http://www.ncbi.nlm. nih.gov/pubmed/18388213

7) Kubota K, Takeno S, Hirakawa K. Frontal recess anatomy in Japanese subjects and its effect on the development of frontal sinusitis: computed tomography analysis. Journal of Otolaryngology - Head \& Neck Surgery = Le Journal d'oto-rhino-laryngologie et de chirurgie cervico-faciale. 2015;44:21. http://www.ncbi.nlm.nih.gov/pubmed/26021826 